\title{
Phenotype variability and basic morphological characteristics of the Aksaray Malakli dog
} population in Turkey

\author{
Milivoje Urošević, Milosava Matejević,* Darko Drobnjak and Umit Ozkanal
}

\begin{abstract}
The Turkish Mastiff or Aksaray Malakli Dog is a Turkish dog breed not yet officially recognized by the world canine organization - Fédération Cynologique Internationale (FCI). To achieve recognition, more research and analysis of the morphometric parameters of this breed are required. Previous research on this breed presented the average values of certain morphological parameters. Measurement results of 20 morphometric
\end{abstract}

parameters showed that there are statistically significant differences in body structure between males and females. Such results are significant for setting the official breed standard in which the proportions of the body characteristic of this breed should be emphasized.

Key words: Turkish Mastiff; Aksaray Malakli; dog breeds; morphometry; morphological traits; guarding dogs

\section{Introduction}

The Turkish Mastiff or Aksaray Malakli Dog is a native Anatolian breed raised in the Aksaray region. This Turkish dog breed has not yet been officially recognized by the world canine organization - Fédération Cynologique Internationale (FCI). According to the FCI, mastiffs belong to Group 2, section (2) molossian type (2.1. mastiff type) (http://fci.be/en/nomenclature/2Pinscher-and-Schnauzer-Molossoidand-Swiss-Mountain-and-Cattledogs.

html). In order to be recognized, more research and analysis of the morphometric parameters of this breed are required. These are guard dogs, strong, with courageous and aggressive characteristics (Kocakaya and Atasoy, 2019). Aksaray Malakli dogs have large body size and weight, large body and head, droopy eyelids, cheeks and lips, large ears, short hair and uncurled tail (Atasoy et al., 2014; Oğrak et al., 2018). Coat colour is usually grey on the body

Milivoje UROŠEVIĆ, DVM, MVM, PhD, Center for Perservation of Indigenous Breeds, Belgrade, Serbia; Milosava MATEJEVIĆ* , (Corresponding author, e-mail: milosava@dgt.uns.ac.rs), PhD, Faculty of Science, University of Novi Sad, Serbia; Darko DROBNJAK, DVM, MSc, Center for Perservation of Indigenous Breeds, Belgrade, Serbia; Umit OZKANAL, PhD, Eskisehir Osmangazi University, Faculty of Education, Eskisehir, Turkey 


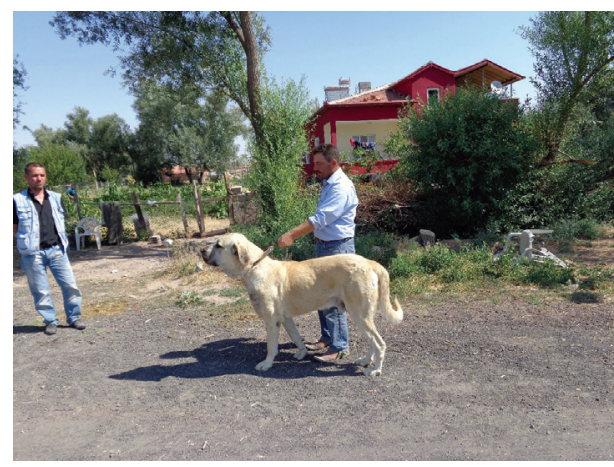

Figure 1. Turkish Mastiff in the natural environment

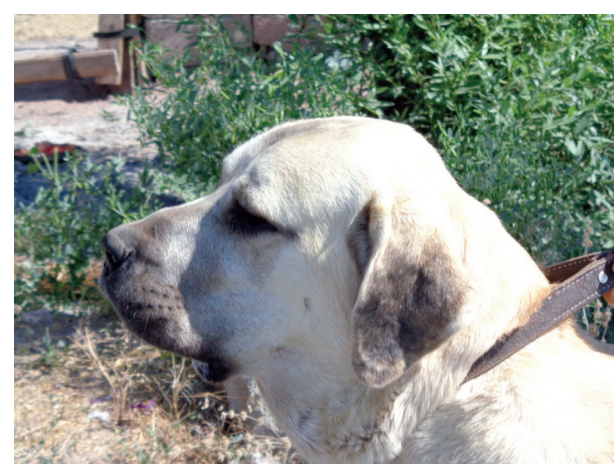

Figure 2. Head profile of Turkish Mastiff

and black and yellow on the head (Büyükleblebici, 2019).

Previous research on this breed reported the average values of certain morphological parameters. Atasoy et al. (2014) indicated that Aksaray Malakli dogs have a strong body structure, with an average height at the withers of $78.36 \pm 0.31 \mathrm{~cm}$ in males, and $72.98 \pm 0.49$ $\mathrm{cm}$ in females. They also reported a mean height at the rump of $78.65 \pm 0.34 \mathrm{~cm}$ in males and $72.87 \pm 0.53 \mathrm{~cm}$ in females. Females had an average body length of $79.02 \pm 0.62 \mathrm{~cm}$, males $82.68 \pm 0.60 \mathrm{~cm}$. Others parameters were: chest girth circumference $84.47 \pm 0.71 \mathrm{~cm}$ in females and $89.89 \pm 0.76 \mathrm{~cm}$ in males; chest depth $30.86 \pm 0.26 \mathrm{~cm}$ in females and $33.73 \pm 0.44$ $\mathrm{cm}$ in males; chest width $24.76 \pm 0.35 \mathrm{~cm}$ in females and $26.68 \pm 0.20 \mathrm{~cm}$ in males; front cannon bone circumference $14.71 \pm 0.12$ $\mathrm{cm}$ in females and $15.76 \pm 0.08 \mathrm{~cm}$ in males; hind cannon bone circumference $13.90 \pm 0.16 \mathrm{~cm}$ in females and $14.76 \pm 0.08$ $\mathrm{cm}$ in males; tail length $51.36 \pm 0.83 \mathrm{~cm}$ in females and $54.76 \pm 0.45 \mathrm{~cm}$ in males. Atasoy et al. (2014) also measured parameters on the head of Aksaray Malakli dogs: head length $30.92 \pm 0.24 \mathrm{~cm}$ in females and $32.98 \pm 0.18 \mathrm{~cm}$ in males; face length $11.80 \pm 0.15 \mathrm{~cm}$ in females and $12.55 \pm 0.09$ $\mathrm{cm}$ in males; ear length $16.73 \pm 0.26 \mathrm{~cm}$ in females and $17.67 \pm 0.17 \mathrm{~cm}$ in males; ear width $13.96 \pm 0.26 \mathrm{~cm}$ in females and $14.78 \pm 0.18 \mathrm{~cm}$ in males. Oğrak et al. (2018) examined the genotypes of the Aksaray Malakli dog breed on a small sample of 10 dogs, and they presented somewhat different results of morphometric trait measurements: wither height mean 80.75 cm (male 80.10, female 71.40), height at the rump $71.45 \mathrm{~cm}$ (male 78.90, female 71.45), body length $99.60 \mathrm{~cm}$ (male 95.40, female 87.10), girth circumference $\mathrm{cm}$ 104.20 (male 101.80, female 96.40), front corpus circumference $19.00 \mathrm{~cm}$ (male 19.40, female 16.90), head length $35.20 \mathrm{~cm}$ (male 36.50, female 31.50), muzzle length $15.40 \mathrm{~cm}$ (male 14.50, female 13.90), body index 123.63 (male 119.06, female 121.71).

The aim of this study was to conduct a detailed analysis of all morphometric parameters that are significant for setting the official breed standard. This paper presents the measurement results of 20 morphometric parameters and their differences by gender and age. It may be an important guideline for breeders, canine organizations and expert commissions, dog judges and other canine workers.

\section{Materials and Methods}

Morphological parameters were measured on a total 44 individuals (22 males and 22 females) representing a population sample of the Turkish mastiff 
breed. All dogs in this sample were bred in Turkey. All measurements were conducted in 2016 in Turkey (Cappadocia region).The following exterior parameters were measured in all dogs: withers height (WH), height of the back (HB), height at rump (HR), height of the tail root (HTR), height of the hock $(\mathrm{HH})$, elbow height $(\mathrm{EH})$, body length (BL), chest depth (CD), chest width $(\mathrm{CW})$, chest circumference (CC), pastern circumference (PC), pelvis length (PL), rump width (RW), rump protuberance width, head length (HL), skull length (SL), head width (HW), muzzle width (MW), muzzle length (ML), ear length (EL). These measurements do not have an invasive character and in no way endanger animal health. All Turkish mastiff dogs were between the ages of 1 and 9 years.

To measure height at the withers, the Lydthin measurement stick was used (Urošević and Drobnjak 2019). For all other parameters, a tape measure was used. All measurements were in centimetres and in accordance with zootechnical standards. Conformation characterization was based on the mean value $(\mathrm{M})$ and standard deviation $(\mathrm{SD})$ of the variables. The T-test was applied

Table 1. Descriptive statistics for morphometric variables in Turkish mastiff $(\mathrm{cm})$

\begin{tabular}{|l|c|c|c|c|c|c|}
\hline & $\mathbf{N}$ & Minimum & Maximum & Mean & $\begin{array}{c}\text { Std. } \\
\text { Deviation }\end{array}$ & Variance \\
\hline withers height (WH) & 44 & 72.00 & 83.00 & 77.34 & 2.74 & 7.53 \\
\hline height of the back (HB) & 44 & 70.00 & 81.00 & 74.60 & 2.58 & 6.66 \\
\hline height at rump (HR) & 44 & 69.50 & 83.00 & 78.83 & 2.66 & 7.09 \\
\hline height of the tail root (HTR) & 44 & 60.00 & 79.00 & 71.86 & 3.32 & 11.05 \\
\hline height of the hock (HH) & 44 & 19.00 & 24.00 & 21.61 & 1.20 & 1.45 \\
\hline elbow height (EH) & 44 & 37.00 & 52.00 & 41.20 & 3.05 & 9.33 \\
\hline body length (BL) & 44 & 76.00 & 91.00 & 82.02 & 3.90 & 15.18 \\
\hline chest depth (CD) & 44 & 32.00 & 40.00 & 35.08 & 1.67 & 2.79 \\
\hline chest width (CW) & 44 & 21.00 & 30.00 & 23.92 & 1.73 & 2.98 \\
\hline chest circumference (CC) & 44 & 87.00 & 107.00 & 94.30 & 5.55 & 30.77 \\
\hline pastern circumference (PC) & 44 & 15.00 & 19.00 & 16.80 & 1.32 & 1.74 \\
\hline pelvis length (RL) & 44 & 17.00 & 27.00 & 19.36 & 1.75 & 3.07 \\
\hline rump width (RW) & 44 & 7.00 & 9.00 & 8.27 & 0.61 & 0.38 \\
\hline $\begin{array}{l}\text { rump protuberance width } \\
\text { (RPW) }\end{array}$ & 44 & 6.00 & 9.00 & 7.35 & 0.61 & 0.37 \\
\hline head length (HL) & 44 & 29.00 & 35.00 & 31.23 & 1.54 & 2.37 \\
\hline skull length (SL) & 44 & 15.50 & 23.00 & 18.69 & 2.37 & 5.60 \\
\hline head width (HW) & 44 & 16.00 & 22.00 & 18.50 & 1.25 & 1.57 \\
\hline muzzle width (MW) & 44 & 7.00 & 12.00 & 8.44 & 1.20 & 1.43 \\
\hline muzzle length (ML) & 44 & 9.50 & 14.00 & 11.00 & 1.10 & 1.22 \\
\hline $\begin{array}{l}\text { ear length (EL) } \\
\text { Valid N (listwise) }\end{array}$ & 44 & 15.00 & 18.00 & 16.52 & 1.07 & 1.14 \\
\hline
\end{tabular}


Table 2. Descriptive statistic for morphometric variables by sex

\begin{tabular}{|c|c|c|c|c|c|}
\hline & Sex & $\mathbf{N}$ & Mean & $\begin{array}{c}\text { Std. } \\
\text { Deviation }\end{array}$ & $\begin{array}{l}\text { Std. Error } \\
\text { Mean }\end{array}$ \\
\hline \multirow{2}{*}{ head length (HL) } & male & 22 & 32.41 & 1.14 & 0.24 \\
\hline & female & 22 & 30.05 & 0.79 & 0.17 \\
\hline \multirow{2}{*}{ skull length (SL) } & male & 22 & 20.64 & 1.68 & 0.36 \\
\hline & female & 22 & 16.75 & 0.86 & 0.18 \\
\hline \multirow{2}{*}{ head width (HW) } & male & 22 & 19.09 & 1.23 & 0.26 \\
\hline & female & 22 & 17.91 & 0.98 & 0.21 \\
\hline \multirow{2}{*}{ muzzle width (MW) } & male & 22 & 9.14 & 1.13 & 0.24 \\
\hline & female & 22 & 7.75 & 0.81 & 0.17 \\
\hline \multirow{2}{*}{ muzzle length (ML) } & male & 22 & 11.18 & 1.14 & 0.24 \\
\hline & female & 22 & 10.82 & 1.06 & 0.23 \\
\hline \multirow{2}{*}{ ear length (EL) } & male & 22 & 17.05 & 1.00 & 0.21 \\
\hline & female & 22 & 16.00 & 0.87 & 0.19 \\
\hline \multirow{2}{*}{ withers height (WH) } & male & 22 & 79.41 & 1.70 & 0.36 \\
\hline & female & 22 & 75.27 & 1.88 & 0.40 \\
\hline \multirow{2}{*}{ height of the back (HB) } & male & 22 & 76.23 & 2.18 & 0.46 \\
\hline & female & 22 & 72.98 & 1.83 & 0.39 \\
\hline \multirow{2}{*}{ height at rump (HR) } & male & 22 & 80.36 & 1.59 & 0.34 \\
\hline & female & 22 & 77.30 & 2.66 & 0.57 \\
\hline \multirow{2}{*}{ height of the tail root (HTR) } & male & 22 & 73.77 & 2.79 & 0.60 \\
\hline & female & 22 & 69.95 & 2.68 & 0.57 \\
\hline \multirow{2}{*}{ height of the hock (HH) } & male & 22 & 21.77 & 1.19 & 0.25 \\
\hline & female & 22 & 21.45 & 1.22 & 0.26 \\
\hline \multirow{2}{*}{ elbow height (EH) } & male & 22 & 43.41 & 2.74 & 0.58 \\
\hline & female & 22 & 39.00 & 1.20 & 0.25 \\
\hline \multirow{2}{*}{ body length (BL) } & male & 22 & 85.09 & 2.27 & 0.48 \\
\hline & female & 22 & 78.95 & 2.50 & 0.53 \\
\hline \multirow{2}{*}{ chest depth (CD) } & male & 22 & 35.98 & 1.65 & 0.35 \\
\hline & female & 22 & 34.18 & 1.14 & 0.24 \\
\hline \multirow{2}{*}{ chest width (CW) } & male & 22 & 24.52 & 1.82 & 0.39 \\
\hline & female & 22 & 23.32 & 1.43 & 0.30 \\
\hline \multirow{2}{*}{ chest circumference (CC) } & male & 22 & 99.00 & 3.35 & 0.71 \\
\hline & female & 22 & 89.59 & 2.32 & 0.50 \\
\hline \multirow{2}{*}{ pastern circumference (PC) } & male & 22 & 17.73 & 1.03 & 0.22 \\
\hline & female & 22 & 15.86 & 0.83 & 0.18 \\
\hline \multirow{2}{*}{ pelvis length (RL) } & male & 22 & 19.55 & 2.22 & 0.47 \\
\hline & female & 22 & 19.1 & 1.14 & 0.24 \\
\hline \multirow{2}{*}{ rump width (RW) } & male & 22 & 8.14 & 0.71 & 0.15 \\
\hline & female & 22 & 8.41 & 0.48 & 0.10 \\
\hline \multirow{2}{*}{$\begin{array}{l}\text { rump protuberance width } \\
\text { (RPW) }\end{array}$} & male & 22 & 7.31 & 0.65 & 0.14 \\
\hline & female & 22 & 7.39 & 0.58 & 0.12 \\
\hline
\end{tabular}


to determine statistically significant differences among individual traits of females and males. The results are presented with the $t$-value $(t)$, degrees of freedom value (df) and significance value (sig).

For the further analysis, the frame (body) index in this population was analysed. According to Urošević and Drobnjak (2019), the body index in dogs is the ratio of body length to height at the withers, calculated by the formula: (body length / height of the withers) $x 100$. For breeds of square body, the index is 100, and if the body index is greater than 100 , then it is a more or less elongated body. As Uroševic and Drobnjak (2019) indicate, if the body index is less than 100 , this means that the height of the withers is greater than the length of the body, which occurs in a small number of breeds.

Croup index represents the ratio of croup height and withers height. If this index has a value of 100 , this means that the height of the withers and height of croup are at the same level. If the croup index is greater than 100, the croup is higher than the withers. The dog has a falling backline when the croup index is less than 100. The croup index is calculated using the formula: croup height / withers height x 100 (Urošević and Drobnjak, 2019).

For further analysis, the skull length index in this population, as the ratio of skull length to head length, was analysed according to Urošević and Drobnjak (2019), which determines head type. The lowest index (40-50) is in the dolichocephalic head type. Moderate index values (50-60) indicate a mesaticephalic head type, while the highest index is obtained for the brachycephalic head type (over 60). The skull length index is calculated using the formula: skull length / head length $x 100$.

An analysis of variance (ANOVA) was conducted to determine differences in the values of measured parameters between age groups in the observed population, where $P$ was set at 0.05 . Collected data were processed using the Statistical Package for Social Sciences software (SPSS for Windows Release 23.0.0).

\section{Results}

Official standards of dog breeds recognized by the FCI include a wide range of morphometric traits. The most important are withers height, body length and chest circumference. However, standards should include more detailed information about the dog breed in order to be useful for breeders, dog judges and other parties. This study included a large number of morphometric variables. The descriptive statistics for the 20 variables used here are shown in Tables 1 and 2 .

The results show that the mean height at the withers was $77.34 \mathrm{~cm}(\mathrm{SD}=2.74)$, which is similar to previous reports (Atasoy et al., 2014). The mean value of body length was $82.02 \mathrm{~cm}(\mathrm{SD}=3.90$, variance $=15.19$ ) .

The variables with the lowest coefficients of variation were: rump protuberance width $(\mathrm{M}=7.35, \mathrm{SD}=0.61)$, rump width $(\mathrm{M}=8.27, \mathrm{SD}=0.61)$, ear length $(\mathrm{M}=16.52, \mathrm{SD}=1.07)$, muzzle length $(\mathrm{M}=11.00, \mathrm{SD}=1.10)$, and muzzle width $(\mathrm{M}=8.44, \mathrm{SD}=1.20)$. The greatest variability was found for chest circumference $(\mathrm{M}=94.30, \mathrm{SD}=5.55)$. Significant variability was also shown in body length $(\mathrm{M}=82.02$, $\mathrm{SD}=3.90$ ) and height of the tail root $(\mathrm{M}=71.86, \mathrm{SD}=3.32)$.

Table 2 shows the differences in the average values of the basic morphometric parameters between males and females. Based on the results obtained with the t-test, it could be concluded that most of the observed basic morphometric parameters showed statistically significant differences by sex, with the exception of muzzle length, height of the hock, pelvis length, rump 
Table 3. Body format index

\begin{tabular}{|l|c|c|c|c|c|c|}
\hline & N & Minimum & Maximum & Mean & $\begin{array}{c}\text { Std. } \\
\text { Deviation }\end{array}$ & Variance \\
\hline Body format index & 44 & 98.72 & 113.75 & 106.07 & 3.83 & 14.63 \\
\hline Valid N (listwise) & 44 & & & & & \\
\hline
\end{tabular}

Table 4. Body format index in males and females

\begin{tabular}{|l|c|c|c|c|c|}
\hline & sex & N & Mean & $\begin{array}{c}\text { Std. } \\
\text { Deviation }\end{array}$ & $\begin{array}{c}\text { Std. Error } \\
\text { Mean }\end{array}$ \\
\hline \multirow{2}{*}{ Body format index } & male & 22 & 107.20 & 3.55 & 0.76 \\
\hline
\end{tabular}

Table 5. Croup index

\begin{tabular}{|l|c|c|c|c|c|}
\hline & N & Minimum & Maximum & Mean & $\begin{array}{c}\text { Std. } \\
\text { Deviation }\end{array}$ \\
\hline Croup index & 44 & 96.53 & 106.58 & 101.95 & 2.10 \\
\hline Valid N (listwise) & 44 & & & & \\
\hline
\end{tabular}

Table 6. Croup index in males and females

\begin{tabular}{|l|c|c|c|c|c|}
\hline & sex & N & Mean & $\begin{array}{c}\text { Std. } \\
\text { Deviation }\end{array}$ & $\begin{array}{c}\text { Std. Error } \\
\text { Mean }\end{array}$ \\
\hline \multirow{2}{*}{ Croup index } & male & 22 & 101.23 & 2.13 & 0.45 \\
\hline & female & 22 & 102.67 & 1.84 & 0.39 \\
\hline
\end{tabular}

width, and rump protuberance width. T-test showed statistically significant difference between males and females for the following morphometric variables: head length $(\mathrm{t}=8.01, \mathrm{df}=42$, $\operatorname{sig}=0.00)$, skull length $(t=9.68, d f=42$, $\operatorname{sig}=0.00)$, head width $(t=3.52, d f=42$, $\operatorname{sig}=0.01)$, muzzle width $(\mathrm{t}=4.68, \mathrm{df}=$ 42 , sig $=0.00)$, chest circumference $(t=$ 10.82, df $=42, \operatorname{sig}=0.00)$, body length $(t$ $=8.54, \mathrm{df}=42$, sig $=0.00)$, elbow height $(t=6.92, d f=28.73$, sig $=0.00)$, height at rump $(t=4.65, d f=42$, sig $=0.00)$, height of the back $(t=5.36, d f=42, \operatorname{sig}=0.00)$, withers height $(t=7.63, \mathrm{df}=34.33$, sig $=$ $0.00)$, chest width $(t=2.45, \mathrm{df}=42$, $\mathrm{sig}=$ $0.02)$, chest depth $(t=4.20, \mathrm{df}=42$, sig $=$
$0.00)$, tail root height $(\mathrm{t}=4.63, \mathrm{df}=42$, $\operatorname{sig}=0.00)$, pastern circumference $(\mathrm{t}=$ $6.59, \mathrm{df}=42, \mathrm{sig}=0.00)$ and ears length $(\mathrm{t}=3.70, \mathrm{df}=42$, sig $=0.01)$. This means that sexual dimorphism is distinctly expressed, and the values of these traits were higher in males than in females.

The format index in dogs is the ratio of body length to height at the withers (Urosevic and Drobnjak, 2019). Consider only the mean values of withers height and body length for the total observed sample of Turkish mastiffs, it can be seen that this population has an elongated body (Table 3). The format index for each individual dog was also calculated, and ranged from 98.72 to 113.75 . Only $2.3 \%$ 
Table 7. Skull length index

\begin{tabular}{|l|c|c|c|c|c|}
\hline & N & Minimum & Maximum & Mean & $\begin{array}{c}\text { Std. } \\
\text { Deviation }\end{array}$ \\
\hline Skull length index & 44 & 53.33 & 74.19 & 59.74 & 5.89 \\
\hline Valid N (listwise) & 44 & & & & \\
\hline
\end{tabular}

Table 8. Skull length index in males and females

\begin{tabular}{|l|c|c|c|c|c|}
\hline & sex & N & Mean & $\begin{array}{c}\text { Std. } \\
\text { Deviation }\end{array}$ & $\begin{array}{c}\text { Std. Error } \\
\text { Mean }\end{array}$ \\
\hline \multirow{2}{*}{ Skull length index } & male & 22 & 63.76 & 5.84 & 1.25 \\
\hline & female & 22 & 55.72 & 1.72 & 0.37 \\
\hline
\end{tabular}

of the sample had a format index less than 100. Thus, the observed population generally has a rectangular body format and there are no varieties with extremely shorter bodies relative to the height of the withers.

When looking at the format index separately by gender (Table 4), males were observed to have a longer average format index that females, indicating that females have a slightly shorter body than males $(\mathrm{t}=2.03, \mathrm{df}=42$, sig $=0.05)$. However, these results further support that the population of Turkish mastiffs is characterized by a proper rectangular body shape.

This population of Turkish mastiffs, generally, is higher at the croup than at the withers (Table 5), with the croup index in the observed sample ranging from 96.53 to 106.58 . However, only $4.5 \%$ of the sample had croup index equal to 100 , and $11.4 \%$ has croup index less than 100.The $\mathrm{T}$ test showed that there was a statistically significant difference in the croup index between males and females, with a more pronounced difference in the height of the croup and the withers in females than in males $(\mathrm{t}=2.41, \mathrm{df}=42$, sig $=0.02$ ) (Table 6).

The skull length index for each individual dog was also calculated (Table 7). The mean value of this index shows that the breed is characterized by a mesaticephalic head type. However, $65.9 \%$ of dogs in the sample had a skull length index between 50 and 60, while in others the skull length index value was greater than 60 .

The T-test showed that there was a significant statistical difference between the skull length index of males and females $(\mathrm{t}=6.193, \mathrm{df}=42, \mathrm{sig}=0.000)$ (Table 8). Accordingly, females have a mesaticephalic head type, while males have a more brachycephalic head type.

\section{Discussion and Conclusions}

In order to obtain the most accurate breed information possible that would be useful to Aksaray Malakli breeders, regular research is required to facilitate establishment of the official breed standard. Recognition as a breed by the FCI is of the utmost importance for the protection of native Turkish mastiff population. The analysis of morphometric parameters requires the measurement of as many traits as possible, to allow for a detailed standard. Little research has been conducted on Turkish mastiffs, with differing results. In order to contribute to and enrich the current knowledge about the Aksaray Malakli breed, this study included the measurement of a larger 
number of morphometric traits than in previous studies.

This study has found that Aksaray Malakli dogs are of rectangular body format, with no varieties in other body proportions. Females have a shorter body, which is contrary to the report of Oğrak et al. (2018) on a sample of 10 dogs. The obtained results for withers height, body length, height at rump, chest depth, chest width, hind cannon bone circumference, muzzle length, ear length reported here also differed from previous studies (Atasoy et al., 2014; Oğrak et al., 2018). Sexual dimorphism was confirmed. Males have a taller and longer body, larger chest circumference and longer and wider head, with a stronger muzzle. There was a statistically significant difference in the skull length index between males and females. Since the population of Turkish mastiffs in Turkey is heterogeneous, it is important that morphometric research on this breed should be conducted on a large number of individuals. It is also important to determined whether the breeding aim will be for dogs with a mesaticephalic or brachycephalic head type, bearing in mind the breathing problems that could occur.

\section{References}

1. ATASOY, F., M. ERDOĞAN, B. ÖZARSLAN, B. YÜCEER, A. KOCAKAYA and H. AKÇAPINAR (2014): Malakli Karabaş köpeklerde bazı morfolojik ve genetik özellikler. Ankara Ünversitesi Veteteriner Fakültesi Dergisi 61, 125-132.

2. BÜYÜKLEBLEBICI, O. (2019): Determination of Some Serum Biochemical Parameters of Aksaray Malakli Breed of Turkish Shepherd Dog. TURJAF 7, 1678-1681.

3. http://fci.be/en/nomenclature/2-Pinscher-andSchnauzer-Molossoid-and-Swiss-Mountain-andCattledogs.html

4. KOCAKAYA, A. and F. ATASOY (2019): Native Dogs Of Turkey, 1.Uluslararasi Tarim Ve Çevre Bilimleri Arastirmalari Kongresi, 07-08 aralik 2019, E-ISBN: 978-605-7594-32-7 (Tarım ve Çevre).

5. OĞRAK, Y. Z., N. ÖZTÜRK, D. AKIN and M. ÖZCAN (2018): Comparison various body measurements of Aksaray Malakli and Kangal Dogs. J. Ist. Vet. Sci. 2, 86-91.

6. UROŠEVIĆ, M. i D. DROBNJAK (2019): Metodologija morfometrije pasa. Kinološka akademija, Beograd, ISBN: 978-86-920293-3-2.

\section{Fenotipska varijabilnost i osnovne morfološke karakteristike populacije pasa aksaray malakli u Turskoj}

Dr. agr. sc. Milivoje UROŠEVIĆ, dr. med. vet. spec., Coar - centar za očuvanje autohtonih rasa, Beograd, Srbija; dr. sc. Milosava MATEJEVIĆ, dipl. ing., docentica, Prirodno-matematički fakultet, Univerzitet u Novom Sadu, Novi Sad, Srbija; mr. sc. Darko DROBNJAK, Coar - centar za očuvanje autohtonih rasa, Beograd, Srbija; Umit OZKANAL, Univerzitet Eskisehir Osmangazi, Edukacijski fakultet, Eskisehir, Turska

Turski mastif ili aksaray malakli je turska pasmina pasa koju Svjetska kinološka organizacija - Fédération Cynologique Internationale (FCI) još nije službeno priznala. Kako bi ova pasmina bila priznata, potrebna su brojna istraživanja i analiza morfometrijskih parametara ove pasmine. Prethodno istraživanje na ovoj aksaray malakli pasmini pokazalo je prosječne vrijednosti nekih morfoloških parametara. Mjerenje rezultata
20 morfometrijskih parametara pokazalo je da postoje statistički značajne razlike u tjelesnoj strukturi između mužjaka i ženki. Takvi rezultati su značajni za postavljanje službenog standarda pasmine $\mathrm{u}$ kojem bi trebalo naglasiti proporcije tjelesnih karakteristika ove pasmine.

Ključne riječi: turski mastif, aksaray malakli, pasmine pasa, morfometrija, morfološka obilježja, psi čuvari 